\title{
17. 多発性骨髄腫の病態と治療の進歩
}

\author{
埼玉医科大学総合医療センター血液内科 木崎 昌弘
}

多発性骨䯣腫 (multiple myeloma) は, B細胞 が終末分化した形質細胞の単クローン性増殖に より惹起される. 平均発症年歯令は 66 歳と高齢者 に好発し, 溶骨性病変, 腎障害, 貧血ならびに 感染症等種々の合併症を伴い, 治癒の難しい難 治性造血器腫瘍である. 無症候のMGUS (monoclonal gammopathy of undetermined significance)からくすぶり型骨髄腫，さらには症候性 骨髄腫と進展し, 症候の認められた時点で治療 を開始する。この進展過程で, 骨髄腫細胞のゲ ノム異常に加え, 周囲の骨髄微小環境や免疫担 当細胞の変化が病態を複雑にしている.

近年, 多くの新規治療薬が開発され, 多発性 骨髄腫の治療成績は格段に向上したが, 治癒を 目指すためには多発性骨髄腫の分子病態を考慮 した治療戦略が必要である. 初回治療を強力に 行うことで腫瘍細胞を極力減らし, さらに維持 療法を継続することで再発を防ぐことが基本で ある. 65 歳未満で重要臓器の機能が保たれてい る初発例には, 自家末梢血幹細胞移植を併用し た大量メルファラン療法が適応となる. 65 歳以 上の症例では, 一般に自家移植の適応にならな いため, 初回寛解導入療法は, 深い奏効を得る ことを目的に, プロテアソーム阻害薬ボルテゾ ミブあるいは免疫調節薬（immunomodulatory drugs：IMiDs）レナリドミドをベースとした治 療を行うが, 最近では, 抗体医薬抗CD38 モノク ローナル抗体ダラツムマブを最初から併用する 強力な導入療法も推奨されている.

再発例の治療は, 1) 宿主要因 (年齢, frailty, PS (Performance Status), 合併症ならびに社会 的要因等), 2) 疾患要因 (染色体異常, 急速な 進行, 髄外腫瘤や形質細胞性白血病等)，3）治 療要因（前治療歴, 治療効果と奏効期間, 前治 療における副作用等）を考慮して決定する．現 在の治療上の問題点は, 再発を繰り返すことで プロテアソーム阻害薬に加えてレナリドミド耐 性となった,いわゆるdouble refractory症例への 対応である.これらに対しては, IMiDsポマリド ミドや新規抗CD38 モノクローナル抗体イサツキ シマブを用いた治療が有用である.さらに，適 切な腫瘍抗原を標的としたCAR-T細胞 (chimeric antigen receptor T-cell) 療法やBiTE (bispecific T-cell engager) 抗体等の免疫療法や新規治療薬, 抗体医薬の開発も盛んに行われており, 多発性 骨髄腫の治療成績のさらなる向上が期待されて いる.

\section{8. 高血圧の最新治療 2021 〜ガイドラインからデジタルハイパーテンション〜}

自治医科大学循環器内科 苅尾 七臣

高血圧が循環器疾患の最大のリスク因子であ ることはよく知られている. 多くの優れた降圧 薬が開発され，実地診療においても容易に使用
可能にもかかわらず，降圧療法中の患者に多く の循環器疾患が発症している現状は「ハイパー テンション・パラドックス」と言われる。この 
現状は，十分な降圧ができていないに他ならな い. 近年発表された国内外の高血圧治療ガイド ラインのキーワードは「より早く, より厳格な, 24 時間にわたる降圧」である（Kario K : Circulation 137 : 543-545, 2018). 早朝高血圧に加え, 血圧日内変動異常で夜間血圧が上昇する riser 型高血圧患者では, 特に心不全リスクが高い. つまり, 早朝高血圧やriser型・夜間高血圧, さ らには，職場での昼間の仮面高血圧を早期に検 出し, 治療管理することが重要となる（Kario K, et al : Circ Res 124 : 990-1008, 2019/Kario K, et al : Circulation $142: 1810-1820,2020)$. 近年で は, 夜間血圧を測定できる家庭血圧計や，精度 検証されている手首式夜間家庭血圧計が利用可 能である（Kario K, et al：J Clin Hypertens, 2021). 日本高血圧学会では, 家庭血圧を指針に した降圧治療を推奨している. 理想的には, ま ず早朝家庭高血圧をターゲットにし，次に夜間 血圧をターゲットにする. パーフェクト 24 時間 血圧コントロールを行うことが望ましい. 早朝 高血圧治療には作用時間が長いカルシウム拮抗
薬やアンジオテンシン受容体拮抗薬, コントロー ル不良の場合にはこれに少量の利尿薬を加える. 夜間血圧の降圧にはミネラルコルチコイド受容 体拮抗薬が有用である（Kario K, et al：Am J Hypertens, 2020). 新規の心不全薬であるSGLT 2 (sodium glucose cotransporter 2) 阻害薬やア ンジオテンシン受容体・ネプリライシン阻害薬 (angiotensin receptor neprilysin inhibitor: ARNI）には明確な降圧作用がみられる（Kario K, et al : Circulation 139 : 2089-2097,2018/Kario K, et al : Hypertension 63 : 698-705, 2014).また, 近年ではデバイス治療である腎デナベーション のピボタル試験の成績も発表されており，2022 年度には臨床導入が検討されている. 本講演で は, 最新の臨床エビデンスとガイドラインを解 説し, ウェアラブルデバイス開発やアプリを用 いた高血圧digital therapeutics等自治医科大学に おけるデジタルハイパーテンション研究の最先 端を紹介する (Kario K, et al : Hypertension 73 : 1240-1248, 2019/Kario K : Hypertension 76 : 640-650, 2020). 